\title{
Explaining Accounting Policy Practices under IFRS: The Role of Institutional Factors
}

\author{
Elena de las Heras (Contact Author) ${ }^{a *}$ \\ elena.delasheras@uam.es \\ Universidad Autonóma de Madrid \\ José Moreira $^{b}$ \\ jantonio@fep.up.pt \\ Universidade do Porto \\ Patricia Texeria $^{b}$ \\ patricia@fep.up.pt \\ Universidade do Porto
}

\footnotetext{
${ }^{\text {a }}$ Universidad Autonóma de Madrid. Departamento de Contabilidad. Facultad de CC. Económicas y Empresariales. Francisco Tomás y Valiente. 28049. Madrid (Spain). Tel.+34 91497 8445. Fax:+34 914978598.

${ }^{\mathrm{b}}$ Universidade do Porto. Facultade de Economia. Rua Dr Roberto Frias. 4200-464. Porto (Portugal)
}

\footnotetext{
* We appreciate the helpful comments and suggestions from Leandro Cañibano, Christof Beuselinck, Begoña Giner, Juan Manuel García Lara, Beatriz Garcia Osma, Allan Hodgson, Michael Neel, Donal Stokes, Luis Rubio, Jose Luis Ucieda and seminar participants at the 2013 Annual Meeting of the American Accounting Association, 2010 Annual Meeting of the European Accounting Association, II Accounting and Finance PhD Symposium and INTACCT Workshops. We acknowledge financial assistance from the European Commission Research Training Network INTACCT (Contract MRTN-CT-2006-035850), the Spanish Ministry of Science and Innovation (ECO2010-19314) and AECA Carlos Cubillo Chair.
} 


\title{
Explaining Accounting Policy Practices under IFRS: The Role of Institutional Factors
}

\begin{abstract}
We argue and document that persistent institutional factors determine managerial accounting policy practice under IFRS. In an analysis of accounting choice across thirteen European countries, we study both overt and covert choices, aggregating them to measure their impact over income, thereby focusing on firm overall accounting strategy and not only on individual choices. Our results indicate that institutional factors significantly explain the observed heterogeneity in accounting policy practices and that firm characteristics have a smaller role in explaining them. Capital market structure and tax-alignment are particularly important factor in driving accounting practice. Contrary to the recent emphasis on enforcement as a key institutional factor, our evidence indicates it is a second order factor, when controlling for other institutional factors.
\end{abstract}

Keywords: $\quad$ Accounting policy practices, International differences, IFRS, institutional factors, managerial reporting incentives

JEL Classification: M41, M44, M47 


\section{Introduction}

Prior research indicates that the wide-world adoption of International Financial Reporting Standards (IFRS) need not result in complete harmonization (Daske et al., 2008; Isidro \& Raonic, 2012; Kvaal \& Nobes, 2012). Indeed, international accounting differences have survived (Nobes, 2013), as has the debate on the differing influence of incentives versus standards on accounting practice (Christensen et al., 2013; Barth \& Israeli, 2013). More research is thus needed to understand why and how accounting practices still differ, and how persistent institutions may shape managerial incentives, leading to international differences in accounting, and limited advances in comparability.

In this paper, we examine the effect of institutional factors on accounting practice under IFRS, controlling for firm-specific characteristics. We focus on how institutional differences shape practice by creating incentives to choose amongst both overt and covert IFRS options to impact on accounting income. ${ }^{1}$ We build on the extant prior literature that shows that accounting has both contractual and valuation implications (see, Cascino et al., 2014, for a recent review), and thus, on the assumption that choice amongst accounting options is not an innocuous exercise, but rather, that it can have significant economic consequences.

It is increasingly becoming a well-accepted fact that the adoption of a single set of accounting standards does not necessarily lead to comparable accounting practices and thus, to comparable financial information, because firms do not consistently select the same accounting policies to record similar transactions. This is potentially explained by the fact that accounting practices (and the underlying managerial reporting incentives) are affected by firm characteristics and institutional factors that are yet to be harmonized (Rahman et al., 2002).

\footnotetext{
${ }^{1}$ We use the terminology in Nobes (2013) and refer to 'overt' options if they are plainly specified as a choice under IFRS; we refer to 'covert' options if no choice is explicitly offered, but the degree of judgement involved allows for the preferences of preparers to be manifested in the choice.
} 
In particular, previous literature argues that country-specific institutional factors largely explain the differences in firms' accounting practices, both pre- (Jaafar \& McLeay, 2007) and post-IFRS adoption (KPMG \& Keitz, 2006; Nobes, 2011; Kvaal \& Nobes, 2012). These prior studies, however, generally focus on country-wide effects, using dummy variables to identify country-effects or using dendograms and cluster analyses to create groups amongst countries (e.g., Leuz, 2010; Nobes \& Stadler, 2013). ${ }^{2}$ Albeit much can be learned from observing country-specific patterns in accounting practice, this prior work does not generally identify specific institutional factors that may influence accounting choice across jurisdictions. We add to this prior literature by researching into how specific institutional factors determine accounting policy practices under IFRS, creating heterogeneity in financial reporting and affecting information comparability.

Our study differs from prior research not only in our choice to focus on the role of specific institutional factors, but also, in our choice of outcome variables. We base our tests on the suggestion in Fields et al. (2001) that accounting policy practices are not isolated decisions, but rather part of an accounting strategy that aggregates the effect of accounting choices. It would appear almost naïve to believe that, when faced with all the options allowed under IFRS on first-adoption and subsequently, managers did so in isolation (standard by standard), without considering the aggregate effects of the individual choices. We argue that managers select individual policies understanding both their individual and aggregate effects, and thus, we focus on accounting strategy, as well as on individual accounting choices.

Concretely, we undertake our tests using a composite measurement score $(C M S)$ that proxies for the firm strategy and is measured as the combined effect on income of a mix of six overt and covert accounting choices that directly influence accounting income: (1) inventory

\footnotetext{
2 Previous studies on the impact of IFRS adoption focus either on firm characteristics (Stolowy and Ding, 2003; Missonier-Piera, 2004; Astami and Tower, 2006; Lourenço and Curto, 2010; Quagli and Avallone, 2010) or on country-specific institutional factors (KPMG and Keitz, 2006; Jaafar and McLeay, 2007; Kvaal and Nobes, 2010; 2012; Haller and Wehrfritz, 2013).
} 
methods; (2) depreciation methods; (3) valuation methods for property, plant and equipment; (4) borrowing cost treatments; (5) research and development cost treatments, and (6) goodwill impairment recognition. Three main reasons justify this selection. First, these practices have a direct impact on earnings. Second, this impact may be classified as being either incomeincreasing or decreasing, allowing us to identify accounting strategies. Finally, they aggregate a variety of different accounting practices capturing firms' accounting discretion and thus managerial reporting incentives (Zmijewski \& Hargeman, 1981; Fields et al., 2001).

The adoption of IFRS in the European Union (EU) in 2005 creates the ideal environment to study the role of institutional factors in potentially deterring the effects of accounting harmonization. Thus, we focus on a subset of EU countries, where, in theory, institutional differences should be at a minimum, given the EU determined efforts to harmonize institutions across countries. Our results, based on a sample of thirteen EU countries, confirm our hypothesis that institutional factors significantly affect accounting strategy choice under IFRS. We report the following key findings. We show that the documented pre-IFRS heterogeneity of accounting practices between countries with different institutional contexts (Jaafar \& McLeay, 2007) persists even after the adoption of a set of common accounting standards. Specifically, we show that managers are less likely to undertake income-increasing accounting practices in countries where capital markets have lower importance and there is high tax-alignment. We also find evidence suggesting that the enforcement influence is secondary to the other two institutional factors. Only in particular situations (e.g. firms with high asset tangibility), managerial firm-specific incentives to adopt income-increasing practices are constrained by strong enforcement. Our results are robust to controlling for firmspecific characteristics. This challenges recent research on IFRS adoption that focuses on enforcement as the fundamental institutional factor (see, e.g., Christensen et al., 2013). 
Our study extends previous evidence along a number of dimensions. First, we provide further evidence on accounting choice under IFRS and how the persistence of overt and covert options may lead to lower comparability. Our evidence adds to that of Kvaal \& Nobes (2010) \& Nobes (2013) in highlighting the potential negative consequences of keeping many options open under IFRS. In particular, by looking at accounting choice in aggregation, rather than only in isolation, our study adds novel evidence to prior work in this area and suggests that managers make use of the flexibility allowed under IFRS, optimizing their choices across a range of policies to meet their accounting objectives. By grouping the choices depending on their consequences, we can overcome the concerns in recent research that accounting system classifications are sometimes spurious and depend on the individual accounting choices analyzed (Nobes \& Standler, 2013).

We also contribute to the literature on the impact of institutional factors on managers' accounting policy practices under IFRS (KPMG \& Keitz, 2006; Nobes, 2011; Haller \& Wehrfritz, 2013) by analyzing overt and covert options not studied in prior research. Also, by studying the impact of institutional factors after controlling for firm characteristics, our study takes into consideration that some of the documented country-level differences in companies' IFRS policy practices (Kvaal \& Nobes, 2010; 2012) may be due to firms selecting different accounting policies to record different economic transactions (Jaafar \& McLeay, 2007). A final contribution is that in our research we include both large and small firms, belonging to a wide number of countries and sectors, thereby adding to prior work by studying countries, choices and firm types not investigated in prior work.

The rest of the paper is organized as follows. Section 2 briefly reviews prior literature on international differences in accounting practices, and section 3 develops the research hypotheses. Section 4 presents the method and section 5 presents, justifies and explains the sample and the empirical results, and section 6 summarizes the main conclusions of the study. 


\section{Evidence on international differences in accounting practices}

Accounting standards harmonization has been widely supported by professionals, regulators and academics, on the grounds that it would improve accounting practice in many countries as well as enhance financial information comparability (Ashbaugh \& Picus, 2001; Barth et al., 2008). However, the recent world-wide move towards a single set of financial standards indicates that complete harmonization of financial reporting may be unattainable, at least, in the short-term, because accounting practices are not determined only by the accounting standards in place (Ball, 2006).

For decades, a strong research effort has been devoted to understanding the reasons behind the existence of different accounting practices to record identical economic transactions (Baker \& Barbu, 2007). The empirical evidence to date identifies the importance of accounting standards in shaping practice, but also, of the incentives of preparers and enforcers of financial reporting (e.g., Ball et al., 2003).

This literature suggests that flexibility in accounting (i.e., standards that allow for policy choices or the absence of precise rules) may be economically preferable in terms of giving managers the discretion necessary to convey their private information to markets, but it also leads to differences in accounting practices, thereby reducing the comparability of financial information across firms (Nobes, 1998). An important finding in this literature is that managers' accounting practices are driven by firm-specific characteristics (Watts \& Zimmerman, 1978; Zmijewski \& Hagerman, 1981; Dhaliwal et al., 1982; Abdel-khalik, 1985) and countries' institutional factors (Ball et al., 2000; Leuz et al., 2003; Burgstahler et al., 2006). The latter are common features to all firms in the same country, such as culture, but 
also, legal, accounting, financial, taxation, and enforcement systems (Nobes, 1983; Dopuch et al., 1988; Gray, 1988; Doupnik \& Salter, 1995; D’Arcy, 2001). ${ }^{3}$

Nevertheless, this evidence is based on the pre-IFRS mandatory adoption period, and mostly on data collected with surveys rather than based on data collected in annual reports. Hence, it remains unclear whether the observed differences in accounting practices across countries were mainly caused by differences in professionals' perceptions or in institutional factors that influence managers' accounting practices. Recent work on mandatory IFRS adoption using data on actual accounting practices provides early evidence on the persistence of differences in those practices across firms with distinct characteristics (Lourenço \& Curto, 2010; Quagli \& Avallone, 2010) and across countries (Kvaal \& Nobes, 2010; 2012). The evidence suggests that countries' institutional factors may determine patterns of accounting practices even under a unique set of accounting standards. Our study thus adds to this research line by testing which specific institutional factors drive accounting practice under IFRS. The following section contains our predictions on the institutional factors that are expected to shape managerial incentives, and thus, to drive accounting choice.

\section{Institutional factors and accounting policy practices: hypotheses development}

Previous studies (Nobes, 1998) have identified the structure of financial markets, the tax regime and the accounting enforcement as the main institutional factors shaping pre-IFRS accounting practices, and have defended that these factors seem to be the most relevant in explaining the differences in IFRS accounting practices in the post-IFRS period (Daske et al., 2008; Nobes, 2011; Isidro \& Raonic, 2012). In this section, we discuss them in turn. We focus

\footnotetext{
${ }^{3}$ Differences in the accounting, financial, taxation, and enforcement systems are country institutional factors given by the culture and legal system of the country.
} 
on the expected impact of the mentioned factors on accounting practices and develop the research hypotheses.

\subsection{Financial markets structure}

Previous studies identify financial market structure (the financial system) as a determinant of managers' accounting practices, because it is relevant in shaping the purpose of financial reporting (D’Arcy, 2001; Stolowy \& Ding, 2003; Cai \& Wong, 2010). Indeed, extant research indicates, for example, that accounting conservatism is demanded by debt-holders (Watts, 2003), and thus, show that conservatism is more pervasive in countries with larger debt markets (Ball et al., 2008).

With regard to their financial systems, countries may be classified in one of two main categories: capital market-oriented and bank-oriented countries (Ali \& Hwang, 2000; Giner \& Rees, 2001). In countries that fit in the first category, companies obtain most of their funds from the market, and investors are legally protected and allowed fair access to public company information. Conversely, in bank-oriented countries, the capital market tends to be smaller, and it is creditors that supply companies with most of the capital they need, tend to control them, and to have direct access to private financial information.

Managers' behavior tends to vary across these financial system types, because in each category the purpose of financial reporting varies. In market-oriented countries, the accounting system and the information it produces serves to protect investors. Shareholders' needs are usually the main driver of the demand for financial information, implying that accounting practices are mainly focused on providing a "true and fair view" of the company. However, the greater the role of capital markets in firms' financing, the stronger the pressure managers feel to beat simple earnings targets, and to signal future cash flows, i.e. the stronger the incentives to use income-increasing accounting practices (Degeorge et al., 1999; Burgstahler \& Eames, 2006). 
Conversely, in bank-oriented countries creditor protection is traditionally considered an important purpose of the accounting system. Thus, accounting practices are driven by a conservative estimation of income, as demanded by creditors, who prefer income-decreasing accounting practices in order for debt covenants violations to surface faster (Watts, 2003). Furthermore, the creditors (mainly banks) may have direct access to relevant financial information or even control firms' financial reporting policies, and thereby suggest the adoption of income-decreasing accounting practices to protect their financial position (Joos \& Lang, 1994; García Lara \& Mora, 2004; Bushman \& Piotroski, 2006).

Although stock listed companies in bank-oriented countries may also come under market pressure, we expect their managers to have lower incentives to adopt income-increasing accounting practices because of high ownership concentration, and/or having banks as major shareholders. In effect, the smaller the capital markets the higher is the importance of banks in the allocation of resources. Hence, we expect in bank-oriented countries managers' incomeincreasing accounting practices to be severely constrained by controlling shareholders and creditors (La Porta et al., 1999). In these countries managers tend to face an incentive to make mostly income-decreasing accounting practices. We thus hypothesize that:

$\mathrm{H}_{1}$ : Managers in countries where capital markets have lower importance are less likely to choose income-increasing accounting practices.

\subsection{Tax regime}

Tax incentives have a strong influence on accounting practices in countries where accounting rules are closely aligned with the tax system. Prior research shows that managers report lower income and avoid income-increasing accounting practices to minimize tax payments (Burgstahler et al., 2006; Jaafar \& McLeay, 2007). 
Tax-alignment is a major factor for the preparation of individual financial statements, which are produced across most EU countries under local GAAP, rather than for consolidated financial statements, because the former are the basis for tax estimation. However, we expect consolidated statements to be also influenced by tax regulations. In effect, the consolidation process implies that accounting policies and procedures for similar transactions under similar circumstances should be uniform among the parent and subsidiaries. Thus, within a group, there may be incentives for firms to choose similar accounting practices, avoiding costly preconsolidation accounting adjustments and/or the costs of having a parallel accounting system for consolidated statements purposes (Kvaal \& Nobes, 2010). Additionally, as mentioned by Gee et al. (2010) and Haller \& Wehrfritz (2013), it is also possible that in some jurisdictions tax authorities may informally compare the accounting practices between the individual and the consolidated statements, giving an extra incentive for firms to adopt the same practices in both. The interview-based evidence in Gee et al. (2010) confirms this view. They report that accountant professionals admit that tax influences exists. Consequently, we expect that the same accounting policy practice is reported under individual and consolidated statements, and thus, that the incentives to minimize income in individual statements influence the choices made when preparing the consolidated statements. Hence, we hypothesize that:

$\mathrm{H}_{2}$ : $\quad$ Managers in countries with large accounting-tax alignment are less likely to choose income-increasing accounting practices.

\subsection{Accounting enforcement}

Enforcement assures the full adoption of IFRS and thereby is a crucial factor to secure comparability of accounting practices and outcomes (Ball et al., 2003; Daske et al., 2008; Christensen et al., 2013). Prior research assigns enforcement a major role in explaining pervading differences across countries in accounting practice after IFRS adoption. Adequate enforcement is predicted to reduce the negative unexpected consequences related to frauds 
(Hope, 2003), minimize discretion permitted under IFRS, and constrain managers' opportunistic incentives to make accounting choices that increase agency costs.

We predict that income-decreasing practices are less likely to be constrained by enforcement mechanisms than income-increasing practices. The latter is more related to managers' and auditors' sanctions because more costly (negative) consequences can result from their adoption. Since companies' liability is limited by their wealth, there are more difficulties to be compensated when frauds results from income overstatement than from understatement (Bushman \& Piotroski, 2006). This can be seen, for example, with financial reporting fraud scandals which resulted from practices that intended to increase income (Feroz et al., 1991; Dechow et al., 1996).

In this context, we expect the strength of the enforcement and the likelihood of disciplinary sanctions underlying the adoption of income-increasing policies to constrain managers' incentives to report high income figures. We thereby expect that managers in countries with strong enforcement will be constrained in their discretion to make incomeincreasing practices. Conversely, in countries with weak enforcement, managers do not face such a constraint, and thus tend to be more willing to manage income upwards. Thus, we hypothesize that:

$\mathrm{H}_{3}: \quad \quad$ Managers in countries with strong accounting enforcement are less likely to choose income-increasing accounting practices.

\section{Research variables and empirical models}

In our empirical approach we examine the effect of institutional factors - capital market structure, tax regime and accounting enforcement - on a composite score of accounting practices under IFRS, controlling for the effect of firm-specific characteristics. In this section, 
we present the definition and measurement of our dependent and independent variables and the models used to test our hypotheses.

\subsection{Dependent variable: Composite score of accounting practices under IFRS}

In line with previous studies (Skinner, 1993; Astami \& Tower, 2006), the dependent variable of our model is a composite score $\left(C M S_{\mathrm{i}}\right)$ that aggregates the impact over income of firms' accounting practices and reflects the company's overall accounting strategy. This score is obtained aggregating a set of six overt and covert IFRS options that impact earnings and it is estimated as follows:

$$
C M S_{i}=\frac{\sum_{k=1}^{6} I M S_{i}}{n_{i}}=\frac{I N V_{i}+D E P_{i}+P P E_{i}+B C_{i}+D C_{i}+G W I_{i}}{n_{i}}
$$

where, $C M S$ is the composite score defined for six categories of accounting practices permitted under IFRS; IMS is the individual method score computed for inventory methods $(I N V)$, depreciation methods $(D E P)$, property, plant and equipment valuation methods $(P P E)$, borrowing costs treatment $(B C)$, development costs treatment $(D C)$ and goodwill impairment treatment $(G W I) ; i$ is the firm indicator and $n$ is the number of categories adopted in the estimation of the score minus the number of non-disclosed or applicable policies $(n \leq 6)$.

These six IFRS options are classified by their impact over earnings. Each IMS takes values ranging from 0 for the most income-decreasing technique to 2 for the most incomeincreasing. Table 1 illustrates the values assigned to each IMS.

\section{Insert Table 1 about here}

The impact on income of each individual accounting policy option on income is justified as follows: 
(1) Inventory methods (INV). The two alternative methods to value inventories under IAS 2 are the FIFO and the weighted average cost. Given the most common situation in industries is input prices increasing over time, the choice of the average cost is considered more incomedecreasing than the FIFO method (Skinner 1993; Astami \& Tower, 2006) because the latter reflects the cost of the oldest purchases in the cost of goods sold or consumed and thus lower input prices. ${ }^{4}$ Hence, $I N V$, the $I M S$ for inventory methods, equals 0 if the company chooses the average cost, it equals 2 if the choice is FIFO and it equals 1 if the choice is a mix of both methods.

(2) Depreciation methods (DEP). IAS 16 defines depreciation as the systematic allocation of the depreciable amount of an asset over its useful life. In this sense, a variety of depreciation methods can be used including straight-line, units of production or diminishing balance methods. These methods just shift income across periods due to the accrual principle, until the assets are sold or revalued. Straight-line depreciation results in a constant charge over the useful asset life; diminishing balance depreciation results in a decreasing charge over the useful asset life and units of production depreciation results in a charge based on the expected use. The use of diminishing balance depreciation method is considered a more income-decreasing technique than the use of the straight-line methods (Skinner, 1993; Dhaliwal \& Heninger, 1999). The units of production depreciation could be either incomeincreasing or decreasing technique. Hence, DEP, the $I M S$ for the depreciation method, equals 0 if the company chooses a diminishing balance method, it equals 2 if the choice is the straight method and it equals 1 if the choice is a mix of methods. To code the use of the units of production method, we have examined each case.

\footnotetext{
${ }^{4}$ According to UNCTAD - United Nations Conference on Trade and Development, the price of commodities over time have been increasing, implying a similar pattern for all other prices in the global economy. Furthermore, this codification is consistent with that chosen in previous papers (e.g. Skinner, 1993; Astami and Tower, 2006). Although, we believe that the codification chosen is the more appropriate one, we have done a sensitivity check by using the measure of accounting method choice strategies that includes all the five choices except that of inventory methods (IAS 2). The results (not reported) support all the inferences explained in the paper. We thank an anonymous referee for raising this question.
} 
(3) Valuation methods for property, plant and equipment (PPE): PPE may be measured using a cost or revaluation model under IAS 16. The former measures the assets at depreciated cost (less any accumulated impairment losses), while the latter reports the assets at fair value through the recognition of gains in equity and losses in income (less subsequent depreciation and impairment). The revaluation model is considered to be the more incomedecreasing technique because it tends to increase depreciation expenses (capitalized gains do not flow through the income statement, as they are recognized in equity). Consequently, $P P E$, the IMS for property, plant and equipment equals 0 if the company chooses the revaluation model, it equals 2 if the choice is the cost model and it equals 1 if the choice is a mix of both methods.

(4) Borrowing costs treatment $(B C)$. At the time of collecting the data for this study, IAS 23 permitted two treatments for accounting borrowing costs, which were the choice of being recognized directly as expenses or the choice of considering them as amortizable assets. ${ }^{5}$ These differentiated treatments could be used to shift income across periods, the latter increasing current income at the expense of future periods. Therefore, the choice of straight recording as expenses is considered a more income-decreasing treatment than recognizing borrowing costs as amortizable assets (Missonier-Piera, 2004). Then, $B C$, the $I M S$ for borrowing costs, equals 0 if a company expenses those costs immediately, and it equals 2 if the choice is to capitalize the costs.

(5) Development costs treatment $(D C)$. Under IAS 38 development costs are capitalized only when they meet certain criteria (technical and commercial feasibility), giving managers flexibility to decide when there is technical and commercial feasibility and permits them to systematically register development costs directly as expenses (Kothari et al., 2002). Capitalized development costs will result in greater income now but less in the future. Hence, the practice of immediate expensing of these costs is considered a more income-decreasing

\footnotetext{
${ }^{5}$ The current treatment of IAS 23 only permits the choice of considering borrowing costs as amortisable assets.
} 
technique than that of recognizing part of them as amortizable intangible assets, particularly in firms that undertake successive development projects. Therefore, $D C$, the $I M S$ for development costs, equals 0 if such costs are immediately expensed and 2 if they are capitalized.

(6) Goodwill impairment (GWI): IAS 36 requires that managers to regularly carry out impairment tests on goodwill based on an estimation of its fair value. However, goodwill impairments are difficult to verify, providing managers with considerable accounting discretion to choose whether to account for the impairment or not (ESMA, 2012; Ramanna \& Watts, 2012). ${ }^{6}$ The practice of recognizing goodwill impairment is considered a more incomedecreasing technique than that of not recognizing it, namely because impairment losses cannot be reversed in the future. ${ }^{7}$ If the company recognizes goodwill impairment $G W I$ equals 0 , otherwise $G W I$ equals 2.

The same codification is used for every IMS when the information on policy practices is non-disclosed or non-applicable. In these cases, the IMS equals 0 and $n$ equals the number of accounting policy practices actually disclosed.

The composite score $(C M S)$ is estimated combining these six IFRS options discussed above. The value of $C M S$ for each company aggregates the impact on income of its accounting policy practices. It takes values ranging from 0 for the most income-decreasing technique, to 2 for the most income-increasing one. Thus, $C M S$ only takes values from 0 to 2 , because each IMS can only take values in the same interval. For example, if a given firm chooses FIFO as the inventory method $(I N V=2)$, the straight-line method as the depreciation

\footnotetext{
${ }^{6}$ Goodwill impairments have been analysed by several studies that provide evidence that firms do not properly register goodwill impairments and indicates that a high number of European companies exist that should recognise goodwill impairment but either do not or delay this choice (e.g. ESMA, 2012; Rammana and Watts, 2012). The evidence also indicates that there is high manager's discretion with regards to goodwill impairments recognition because the choice to make goodwill impairments may be delayed.

${ }^{7}$ In the current study we only consider the decision of impairments for the year 2005, which is the first year of compulsory IFRS adoption. Although this is not the ideal solution, because the company has to make tests for impairment every year, we believe that the first year's decision is a good indicator of future accounting tendency. Nevertheless, if CMS (the composite score) is calculated excluding the impact of the goodwill strategy, the results and the inferences remain unchanged.
} 
method $(D E P=2)$, the cost model for PP\&E valuation $(P P E=2)$, it takes borrowing costs into the income statement $(B C=0)$, it does not disclose (or it is not applicable) information on development $\operatorname{costs}(D C=0$ and $\mathrm{n}=5)$ and does not make goodwill impairments $(G W I=2)$, the total score would be calculated as $C M S=(2+2+2+0+0+2) / 5=1.6$. The closer the score to 2 , the more income-increasing is the firm's chosen strategy.

Our measure thus combines both overt and covert accounting options. Previous research (e.g. Nobes, 2011; Haller \& Wehrfritz, 2013) focuses on overt options. In our study, the options for inventory method, depreciation method, PP\&E valuation and borrowing costs treatment are overt options, that is, they are plainly specified as a choice under IFRS. In addition to those, we consider covert options by examining the options for development costs treatment and goodwill impairment because, although these options are not explicitly offered under IFRS, the degree of judgment involved allows for the preferences of preparers to be manifested in the choice.

Finally, we must point out that the effect on income of some of the analyzed accounting options (e.g. inventory method, PP\&E valuation and goodwill impairment) affects the present but not the future; while the effect on income of others (e.g. depreciation method, borrowing costs and development costs) may reverse at a later point in time. Nevertheless, the effect of the choice of the straight line method as the depreciation method or of the choice to capitalize borrowing and development costs can lead to a higher income in earlier periods, but lower in later periods. In our analysis, we denote as income-increasing (decreasing) those practices that accelerate (delay) the reporting of gains. The potential (future) reversal related to those practices is expected not to be an issue in our study, because we test the determinants of managers' accounting policy choice and overall, consider that the chosen methods tend to be stable over time as imposed by IFRS and that managers' accounting practices are usually driven by the expected short term income effect. 


\subsection{Main independent variables: Institutional factors}

To examine how institutional factors influence accounting policy practice, we introduce three institutional variables that proxy for the capital market structure, tax regime and accounting enforcement, respectively. First, the capital market structure $(L M K)$ is measured as the negative value of the ratio of market capitalization for all listed company stock to GDP obtained from the World Bank (Kaufmann et al., 2007). The higher the $L M K$, the lower is the importance of the capital market. Second, to examine the influence of the link between tax and accounting on policy practice, we incorporate the variable $T A X$ provided by Burgstaler et al. (2006) which is measured as the average corporate tax rate in percent of earnings before taxes obtained from the IMD World Competitiveness Yearbook (2000) when tax and accounting are closely aligned, and 0 when tax and accounting are not closely aligned. Third, accounting enforcement $(E N F)$ is considered by including the index provided by La Porta et al. (2006) for public enforcement that equals the arithmetic mean of the following five subindexes: (1) supervisor characteristics index; (2) rule-making power index; (3) investigative powers index; (4) orders index; and (5) criminal index. The values of these five subindexes range between 0 and 1 . Hence, public enforcement is a continuous variable that ranges between 0 and 1 . Greater values of the index are associated to stronger enforcement.

\subsection{Control variables: Firm-specific characteristics}

Besides the institutional factors, we also include several firm characteristics to control for the potential effects of these variables on accounting choice. Consistent with previous studies, we rely on contracting theory to underpin the relationship between firm characteristics and accounting policy practices under IFRS (Jensen \& Meckling, 1976, Watt \& Zimmerman, 1978; Zmijewski \& Hagerman, 1981). Specifically, this literature highlights the influence on 
accounting practices of the following firm-specific characteristics: Financial leverage ( $L E V)$ measured as total liabilities divided by total assets (Beneish \& Press, 1993); Ownership dispersion (DISP) measured as the percentage of widely held shares (Chizema, 2008); Asset specificity $(A S P)$ calculated as total R\&D expenses deflated by total assets (Missonier-Piera, 2004); Investment opportunity set (IOS) calculated as the firm's market value divided by book value of total assets (Missonier-Piera, 2007); Assets tangibility (TAN) measured by total net property, plant and equipment divided by total assets (Astami \& Tower, 2006); Political costs (SIZE) measured as the logarithm of total assets; and Industries effects (IND) included as a group of dummy variables (Jaafar \& McLeay, 2007).

Generally, we expect that the higher the leverage ratio $(L E V)$ the more willing the managers are to make income-increasing accounting practices to avoid debt covenant violations (Watt \& Zimmerman, 1978; Zmijewski \& Hagerman, 1981; Dhaliwal et al., 1982). Furthermore, we also expect that the higher the level of ownership dispersion in firms (DISP), the less control shareholders have over firms' accounting information and financial reporting policies and then, the higher the flexibility is for managers to make discretionary incomeincreasing practices to increase their own compensation (Dhaliwal et al., 1982; Abdel-khalik, 1985; Niehaus, 1989).

Concerning agency costs, we also expect that the greater the firms' asset specificity (ASP) and investment opportunity set $(I O S)$, the more willing their managers are to make incomeincreasing accounting practices to improve the firms' financial ratio and reduce the increased risk as perceived by creditors and investors of these kind of firms (Williamson, 1983; Niehaus, 1989; Smith \& Watts, 1992; Skinner, 1993; Dhaliwal et al., 1999; Missonier-Piera, 2004). Additionally, the higher the asset tangibility (TAN) the more adequate the accounting figures become as performance measures. Consequently, high asset tangibility increases the use of accounting figures for both compensatory and debt contracts as well as the managers' 
incentives to make income-increasing accounting practices to improve their own compensation and reduce credit risk (Skinner, 1993, Astami \& Tower, 2006).

Prior evidence also indicates that larger firms (SIZE) are more likely to use incomedecreasing accounting practices in order to reduce their inherent political costs (Watt \& Zimmerman, 1978; Zmijewski \& Hagerman, 1981; Hand \& Skantz, 1997). Finally, our model also controls for industry effects (IND) because it may be possible that accounting policy practices are predetermined by certain industry practices (Jaafar \& McLeay, 2007).

\subsection{Empirical model}

Our research aims to identify the influence of key institutional factors as determinants of accounting policy practices under IFRS, after controlling for firm characteristics. To do this, we use the following Tobit model: ${ }^{8}$

$$
\begin{aligned}
C M S_{i, j} & =\alpha+\delta_{1} L M K_{j}+\delta_{2} T A X_{j}+\delta_{3} E N F_{j} \\
& +\beta_{1} L E V_{i, j}+\beta_{2} \operatorname{DISP}_{i, j}+\beta_{3} A S P_{i, j}+\beta_{4} I O S_{i, j}+\beta_{5} T A N_{i, j}+\beta_{6} S I Z E_{i, j} \\
& +\sum_{k=1}^{4} I N D_{i, j}+\varepsilon_{i, j}
\end{aligned}
$$

Where, $i$ and $j$ denote firm and country subscripts, respectively. The dependent variable, $C M S$, is the composite score summarizing the impact on income of firms' accounting policy practices, as defined in section 4.1 above. The independent variables consist of specific country-level institutional variables and those reflecting company characteristics.

To test $\mathrm{H} 1$ we use the institutional variable $L M K$. We expect that managers operating in countries with smaller capital markets are less likely to adopt accounting methods that increase reported income. Thus, we expect a negative correlation between the composite measure score $(C M S)$ and the variable $L M K$. Concretely, we expect the coefficient $\delta_{1}$ to be

\footnotetext{
${ }^{8}$ Given that $C M S$ is a truncated limited variable, a TOBIT model is more appropriate to test the hypotheses discussed above. An OLS model does not fit our needs because it may predict values from $-\infty$ to $+\infty$, which are outside the dependent variable range ( 0 to 2 ), and it is likely to produce inconsistent estimators.
} 
negative and significant. To test $\mathrm{H} 2$ we use the institutional variable $T A X$. We expect that managers in tax-aligned countries are less likely to adopt income-increasing accounting practices. We thus expect a negative correlation between $C M S$ and $T A X$ as reflected in a negative and significant coefficient $\delta_{2}$. Finally, to test H3 we use the institutional variable $E N F$. We expect that managers in countries with strong enforcement are less willing to make income-increasing practices. Thus, we expect a negative correlation between $C M S$ and $E N F$ and thus, a negative and significant $\delta_{3}$ coefficient.

The expected signs for the variables controlling for firm-specific characteristics are described as follows. Based on the comments in section 4.3 above, a positive correlation is expected between the dependent variable $(C M S)$ and the firm's leverage ratio $(L E V)$, ownership dispersion $(D I S P)$, asset specificity $(A S P)$, investment opportunity set $(I O S)$ and asset tangibility $(T A N)$. Thus, we expect the coefficients $\beta_{1}, \beta_{2}, \beta_{3}, \beta_{4}$, and $\beta_{5}$ to be positive and significant. This means that the higher a firm's leverage, ownership dispersion, asset specificity, investment opportunity set and asset tangibility, the more likely managers are to make income-increasing accounting practices. Conversely, we expect a negative correlation between the dependent variable $(C M S)$ and company size (SIZE) indicating that the larger the firm, the more likely managers will make income-decreasing accounting practices; thus, we expect the coefficient $\beta_{6}$ to be negative and significant.

\section{Results and data}

\subsection{Sampling process}

We use a sampling method to select our working sample of European companies. This is done so that the sample used is representative of the entire population of consolidated listed companies in WorldScope. See Appendix 1 for a detailed explanation on the sampling 
process. The initial population comprises 1,891 European companies that transition to IFRS on the year 2005. The final working sample consists of 344. Both the initial and working samples comprise companies from thirteen countries (Austria, Belgium, Denmark, Finland, France, Germany, Ireland, Italy, Netherlands, Portugal, Spain, Sweden and the UK) and four main industrial sectors (SIC 20-39 Manufacturing, SIC 40-49 Transportation, communications, electricity, gas, and health services; SIC 50-59 Wholesale and retail trade; and SIC 70-89 Services). ${ }^{9}$ Table 2 displays the initial population of European listed companies in our study and the subsequent working sample. ${ }^{10}$ Both samples are classified by country and industry.

Insert Table 2 about here

\subsection{Descriptive statistics}

Financial data is collected from WorldScope; data on accounting practices is manually collected from company annual reports. Table 3 displays descriptive statistics on individual accounting practices, providing an overview by country and type of practice. It shows that the inventory method choice is the most heterogeneous of all the practices: $35 \%$ of the companies adopt the income-decreasing practice (average cost method) while $32 \%$ choose the incomeincreasing one (FIFO method). Conversely, it shows that companies tend to adopt the same method choice for valuation of PP\&E and depreciation methods. $97 \%$ and $89 \%$, for valuation and depreciation, respectively, adopt the income-increasing practice (cost model for valuing PP\&E; straight method for depreciation).

\footnotetext{
${ }^{9}$ To obtain a proper stratified random sample, we needed groups with homogeneous companies. Thus industrial sectors with fewer than 100 firm-per-year observations were removed. In addition, services firms (SIC 91-99) and financial, insurance and real estate firms (SIC 60-67) were also excluded from our initial industries because of their particular characteristics that translate into specific financial statements models.

${ }^{10}$ The equality of distributions (Wilcoxon Z-test) and specific parameters (T-test) tests support the preliminary assumption that both the initial and stratified samples do not differ from each other significantly. The authors will provide these test results upon request.
} 
Table 3 also evidences that European companies not always choose the income-increasing practice of capitalizing costs. They tend to choose capitalization of development costs $(45 \%)$, but not of borrowing costs (14\%). Additionally, only $17 \%$ of the companies in the working sample recognize goodwill impairment in the first year of application, adopting an incomedecreasing practice. Finally, this table shows that the distribution of the accounting practices by country tends to be relatively homogenous, and that there are still companies in the sample that do not disclose information about their accounting practices.

Insert Table 3 about here

Table 4 provides descriptive statistics on the variables of the model for the whole sample and across countries. The composite measure score $(C M S)$ has a mean and a median $($ mean $=1.47$, median $=1.50)$ greater and statistically different from $1(p<0.01)$. This means that, on average, companies tend to adopt income-increasing accounting practices. The breakdown of the information by country suggests that it is managers from Denmark $($ mean=1.67), Sweden $($ mean=1.67) and Ireland (mean=1.70), who, on average, seem to make the most income-increasing practices while those from Portugal (mean=1.16), Germany (mean=1.33) and Italy (mean=1.38), average out with the most income-decreasing practices. The results (not reported) from a $t$-test statistical analysis comparing the country mean with the whole sample mean, reveals significant statistical differences for Denmark, Sweden, Portugal and Germany. These results clearly identify managers from Denmark and Sweden (Portugal and Germany) as income-increasing (income-decreasing) preparers.

Additionally, Table 4 provides descriptive statistics on the institutional factors. The capital markets structure variable $(L M K)$ ranges from -3.61 (for Portugal) to -13.4 (for the UK), with lower values corresponding to greater importance of the capital markets. As expected, the UK, Sweden, Finland, Netherlands, Spain and France are the countries that show higher influence of the capital markets, all of them scoring below the mean. The 
variable $T A X$, as defined, takes values of zero for Denmark, Ireland, Netherlands and UK indicating that they are low tax-alignment countries. Conversely, the variable $T A X$ for the rest of the countries ranges from 0.28 (for Finland and Sweden) to 0.53 (for Germany) with higher values corresponding to stronger influence of the tax on accounting. ENF statistics range from 0.15 to 0.77 , with higher values corresponding to stronger enforcement. The data show that Finland $(E N F=0.77)$ and the UK $(E N F=0.68)$ have the highest score and thereby, the strongest public enforcement system while Austria $(E N F=0.17)$ and Belgium $(E N F=0.15)$ have the weakest.

The descriptive statistics for the firm-specific characteristics control variables are also displayed, and tend to be in line with those provided in previous studies (Burgstalher et al., 2006).

Insert Table 4 about here

Table 5 displays the correlation matrix, with Pearson and Spearman coefficients, respectively, above and below the diagonal. As expected, there is a negative and statistically significant correlation between the dependent variable $C M S$ and the institutional variables, $L M K, T A X$ (significant at 0.1 levels), consistent with the predictions underlying $\mathrm{H} 1$ and $\mathrm{H} 2$. The negative sign on these correlations suggests that the lower the importance of capital markets and the higher the alignment between the tax and accounting systems are the less likely firms adopt income-increasing accounting practices. Conversely, and unexpectedly, there is a positive and statistically significant relation in between $C M S$ and ENF (significant at 0.05 levels). This result indicates that the enforcement is not constraining the adoption of income-increasing accounting practices, thus, it does not provide initial support for $\mathrm{H} 3$.

Consistent with previous findings (Nobes, 1998; Leuz et al., 2003; Burgstahler, et al., 2006), the correlation coefficients amongst the institutional variables are considerably high (significant at the 0.01 levels). This indicates that non tax-aligned countries with strong 
enforcement tend to be capital market-oriented. To avoid multicolinearity problems due to the high correlation between these three explanatory variables, and following prior research, we present the institutional variables alternately in the model (Leuz et al., 2003; Burgstahler, et al., 2006). By doing so, the values of the correlation coefficients for the independent variables in the model (one institutional factor and all firm-specific characteristics) tend to be reduced (less than $40 \%$ ).

Insert Table 5 about here

\subsection{Main results: Estimations across countries controlling for firm-specific characteristics}

Table 6 displays the estimated coefficients for model (2). The five regressions presented are differentiated by the combination of relevant institutional variables each one adopts. Columns (1), (2) and (3) show the effect of institutional factors separately and include variables of firm characteristics to control for leverage, ownership dispersion, assets specificity, investment opportunity set, asset tangibility, size and industry effects. Column (1) shows the impact of capital markets structure $(L M K)$ on accounting policy practices; column (2) the impact of the tax system (TAX); column (3) the impact of the enforcement (ENF) and column (4) the impact of the institutional factors altogether; finally, column (5) shows the effect of firm characteristics without considering institutional factors.

The coefficient of $L M K$ in column (1) is negative and significant (coeff=-0.03, $p$ value<0.01). This evidence suggests that in countries which are less capital market-oriented, companies' adoption of income-increasing accounting practices is less likely. In these countries the pressure of the bank system on managers to report earnings more conservatively tends to be more intense than the pressure of the capital market to beat analysts' forecasts and avoid decreases in earnings. This result supports H1. 
The coefficient of $T A X$ in column (2) is negative and significant (coeff $=-0.62, p$ value $<0.01)$. This result indicates that firms from tax-aligned countries are less likely to make income-increasing practices, because higher income does translate into higher taxes. The result thereby, provides evidence to support $\mathrm{H} 2$.

The coefficient of ENF in column (3) is positive and significant (coeff=0.26, $p$ value $<0.05)$. Contrary to $\mathrm{H} 3$ the result does provide evidence indicating that firms from countries with strong enforcement are more likely to make income-increasing practices. A possible explanation for this unexpected finding is that the accounting policy practices examined are within the accounting standards, and thus tend to be not deeply affected by the degree of enforcement. Another possible explanation for this finding is that managers in countries with strong enforcement may be more willing to use income-increasing practices when necessary to better reflect the underlying economics of the firms. Furthermore, given that countries with a high degree of enforcement tend to have developed capital markets, and these positively affect the adoption of income-increasing accounting practices, the unexpected result we got may be driven by the impact of capital markets. Therefore, this tends to be an innovative result that brings a better perception of the impact of the enforcement over managers' accounting practices.

Results in column (4) show coefficients on three institutional factors variables are taken jointly. These results are consistent with the previous explanation, suggesting that the capital markets impact prevails over that of the enforcement when we deal with accounting practices within the accounting standards. Also, the maximum value of the variance inflation factor (VIF) across the independent variables, which is the VIF value of $L M K(\mathrm{VIF}=2.72)$, indicates multicollinearities between the institutional independent variables. Concretely, the variable $L M K$ could be considered as a linear combination of $E N F$. 
Finally, results in column (5) show that when no institutional factors are considered in the models the explanatory power of the model (Pseudo R2) decreases by half, suggesting that such factors are important in explaining managers' accounting policy practices.

The results also show some association between managers' accounting practices and firm characteristics, but less than expected. Only two out of six characteristics considered in the analysis are significantly affecting such practices. One is the investment opportunity set $(I O S)$, with a positive and significant coefficient in all columns. Companies with a high bundle of investment opportunities tend to make more income-increasing accounting practices, probably to show better financial health and justify the financing they need to collect from banks and the market. The other firm characteristic is the ownership dispersion $(D I S P)$, whose coefficient is positive and significant in columns (3) and (5). This evidence suggests that the higher the level of firms' ownership dispersion the higher managers' flexibility is to make discretionary income-increasing practices. However, the coefficient of $D I S P$ is quite small and insignificant after controlling for the effects of the financial and taxation systems, suggesting that the impact on accounting practices is not very strong. The coefficients of the remaining variables ( $L E V, A S P, T A N$ and SIZE) are not significant in explaining accounting practices, suggesting that the bulk of firm-specific variables influencing managers' practices tend to be smaller than the literature reports (Zmijewski \& Hagerman, 1981; Rahman et al., 2002; Missonier-Piera, 2004; Astami \& Tower, 2006).

\section{Insert Table 6 about here}

Overall, the results tend to be in line with the expectations and indicate that accounting practices under IFRS are significantly influenced by differences in the capital markets structure and the tax regime across European countries. Our evidence is consistent with prior literature (Jaafar \& McLeay, 2007; Kvall \& Nobes, 2010, 2012), concerning how institutional factors influence managers' accounting policy practices, and on the smaller role played by 
firm characteristics in these practices. This means that it is not enough to have a common set of accounting rules - the case in Europe since 2005 - to achieve harmonized accounting information. In effect, financial reporting under IFRS cannot be compared accurately across European countries, because the standards are not being interpreted or applied consistently due to the impact of institutional factors. In order to achieve international harmonization of accounting practices, intervention into the basic institutional factors that shape each country is therefore needed.

\subsection{Additional results and sensitivity analyses}

\subsubsection{Interactions between institutional factors and firm characteristics}

To further research the role of institutional factors in accounting policy practices, we also examine how these factors interact with managers' incentives created by firm-specific characteristics. To do so, we run the following TOBIT model:

$$
\begin{aligned}
& C M S_{i, j}=\alpha+\delta_{1} \text { Intitutional }_{j} \\
& \quad+\beta_{1} \text { LEV }_{i, j}+\beta_{2} \text { DISP }_{i, j}+\beta_{3} \text { ASP }_{i, j}+\beta_{4} \text { IOS }_{i, j}+\beta_{5} \text { TAN }_{i, j}+\beta_{6} \text { SIZE }_{i, j} \\
& \quad+\rho_{1}(\text { Intitutional } * \text { LEV })_{i, j}+\rho_{2}(\text { Intitutional } * \text { DISP })_{i, j}+\rho_{3}\left({\text { Intitutional } * A S P)_{i, j}}\right. \\
& \quad+\rho_{4}(\text { Intitutional } * I O S)_{i, j}+\rho_{5}(\text { Intitutional } * \text { TAN })_{i, j}+\rho_{6}(\text { Intitutional } * \text { SIZE })_{i, j} \\
& \quad+\sum_{k=1}^{4} I_{i N D_{i, j}}+\varepsilon_{i, j}
\end{aligned}
$$

Model (3) extends model (2) incorporating the binary definition of the three institutional factors variables and six interactive variables that conjugate alternatively the effect of one institutional factor and firm characteristics. We transform the three continuous institutional factors variables ( $L M K, T A X$ and $E N F)$ into binary variables ( $L M K D, T A X D$ and $E N F D)$ by using the median to split them into two classes, except for $T A X$ where 0 percent is used as a cut-off (Burgstahler et al., 2006; Bushman \& Piotroski, 2006; Daske et al., 2008). We expect the predicted effects of the institutional factors that capture differences in the capital market structure $(L M K D)$, tax regime $(T A X D)$ and enforcement $(E N F D)$ to negatively influence the 
managerial incentives created by the firm-specific characteristics (LEV, DISP, ASP, IOS, TAN and SIZE). Thus, we expect coefficients $\rho_{1}, \rho_{2}, \rho_{3}, \rho_{4}, \rho_{5}$, and $\rho_{6}$ to be negative and significant, meaning that managers in countries with lower importance of the capital markets, high taxalignment and strong enforcement have weaker managerial incentives to manage income upwards. Specifically, we expect the institutional factors that reflects low importance of the capital market, tax-alignment and/or strong enforcement to constrain (enhance) firm-specific managerial incentives to manage income upwards (downwards). These expected results will provide further evidence to support respectively, $\mathrm{H} 1, \mathrm{H} 2$ and/or $\mathrm{H} 3$.

Table 7 displays the results of running model (3). Columns (1) and (2) shows the impact of capital markets structure (institutional $=L M K D$ ); columns (3) and (4) the impact of the tax system (institutional= TAXD); and columns (5) and (6) the impact of the enforcement (institutional $=E N F D)$.

Insert Table 7 about here

Results in columns (1) show a negative and significant coefficient on LMKD (coeff=$0.18, p$-value $<0.01)$ and positive and significant coefficients on the firm characteristics DISP and IOS. Thus, they are consistent with those in section 6.1. Additionally, results in column (2), that includes the interactions variables between $L M K D$ and the firm characteristics, show negative coefficients on most of these interactions. This indicates that the incentives to adopt income increasing practices provided by firm characteristics might be constrained in countries where capital markets have lower importance; but the coefficients are not statistically significant, suggesting that the impact of managerial firm characteristics on accounting practices is unaffected by $L M K D$. Only the positive and significant coefficient on IOS (coeff $=0.06, p$-value $<0.01)$ provides significant evidence suggesting that managers of firms with high investment opportunity in countries with high importance of capital markets seem to have strong incentives to make income-increasing accounting practices that firms with the 
same firms' characteristic in countries with low importance of the capital markets. Hence, the results do provide limited evidence indicating that the managerial incentives created by specific firm characteristics are influenced by the financial system.

Results in columns (3) show a negative and significant coefficient on TAXD (coeff $=-0.20$, $p$-value $<0.01)$ and only positive and significant coefficients on IOS. Thus, they are consistent with those in section 6.1. Moreover, results in column (4) show negative coefficients on most of the interactions variables between $T A X D$ and the firm characteristics. This indicates that the incentives to adopt income increasing practices provided by specific firm characteristics might be constrained in tax-alignment countries. However, the coefficients are not statistically significant. Hence, the results do not provide enough evidence to support that the managerial incentives created by specific firm characteristics are influenced by the taxation system.

Finally, results in columns (5) show a positive and significant coefficient on ENFD (coeff=-0.12, $p$-value $<0.01)$ and only positive and significant coefficients on IOS. These results are consistent with those of section 6.1. Interestingly, the results in column (6) with the interactive variable on ENFD show some remarkable results. The coefficient on the interactive variable $E N F D * T A N$ is negative and significant (coeff=-0.79, $p$-value $<0.01$, meaning that for a given degree of enforcement, companies with high asset tangibility are less likely to adopt income-increasing accounting practices. The results show a positive and significant coefficient on $\operatorname{TAN}$ (coeff=0.54, $p$-value $<0.01$ ) indicating that managers of firms with large amounts of tangible assets, which usually use accounting numbers in stakeholders' contracts, have strong incentives to improve firms' financial ratios by making incomeincreasing accounting practices, but these incentives seem to be constrained in countries with strong enforcement. These results indicate that the enforcement is an institutional factor that constrains the managerial incentives to manage income upwards for the case of firms with high asset tangibility, and thus, provide slight evidence to support H3. 


\subsubsection{Alternative proxies for the dependent variable}

Another robustness test is performed by using a set of additional aggregate measures of the accounting policy practices. Only composite scores are used as alternative dependent variables because there is no sufficient heterogeneity to run separate analyses by each Individual Method Score (IMS). The three alternative composite scores created dropped the accounting practices which could have a less clear impact on income. The new scores (CMS5, $C M S 4, C M S 3)$ differ from the main one $(C M S)$ in the number of accounting policies practices included. The first alternative score (CMS5) incorporates all the practices from the main score but the valuation method for PP\&E (IAS 16). In our research this practice has been considered as an income-increasing one. However many accounting practitioners would probably consider the revaluation method the more aggressive accounting method as it increases asset values beyond cost minus depreciation and boosts equity. The second alternative score (CMS4) incorporates all the practices included in the previous score (CMS5) but that of goodwill impairment (IAS 39), which was excluded because its impact on income may not be constant across periods. Given our work is focused in only one year (2005), the impact of this accounting practice on income may not be straightforward. The third alternative score $(C M S 3)$ incorporates all the practices included in $C M S 4$ except that of depreciation methods (IAS 16). CMS3 includes only the three accounting practices that we may consider stronger in terms on their clear impact on income: inventory valuation, borrowing costs, and development cost. In all situations, the results (not reported) are similar to those discussed in sections 6.1 and 6.2 .

\subsubsection{Alternative proxies for the institutional variables}

Additional tests are also performed to check the robustness of the institutional factors' variables. Different proxies for Institutional are defined, and models (2) and (3) are reestimated. Firstly, for the impact of the capital market on accounting practice we use the 
negative value of the proxy Importance of Equity Market provided by Leuz et al. (2003). Secondly, to proxy for differences in the tax regimes across countries we use a dummy variable provided by previous studies (Hung, 2001; Burgstahler et al., 2006) that takes the value of 1 when tax rules and accounting rules are closely aligned, 0 otherwise. Finally, for the influence of the enforcement on accounting practices under IFRS, and despite the difficulty to measure this influence (Hope, 2003; Leuz, 2010), we have identified a proxy for the enforcement of IFRS in Christensen et al., (2013) that takes the value of 1 if the country implemented the mandatory IFRS adoption with proactive reviews in 2005,0 otherwise. The results (not reported) are similar to those discussed in sections 6.1 and 6.2.

\subsubsection{Controlling for the effect of voluntary and mandatory IFRS adopters}

The robustness of our results is also analyzed by considering the existence of voluntary and mandatory IFRS adopters which has been suggested that may affect accounting practices in different ways (Daske et al., 2008). To control for this additional effect, we re-run model (2) including a dummy variable, voluntary, that takes value 1 if the company has adopted IFRS previous to the year 2005 and 0 otherwise. The results (not reported) show that the coefficients on the variable voluntary in all models are not significant. Hence, we do not find empirical evidence that supports the voluntary (mandatory) IFRS adoption may have affected managers' accounting practice. The remaining results are similar to those discussed in sections 6.1 and 6.2.

\section{Summary and Conclusions}

We examine the impact of institutional factors on managers' accounting policy practices under IFRS using a sample of companies from thirteen EU countries. Our results show that accounting practices are significantly influenced by institutional factors. Specifically, we show that managers are less willing to make income-increasing practices in countries with 
weak capital markets and high tax-alignment. We also find evidence suggesting that the enforcement influence is secondary to the other two institutional factors. Only in particular situations (e.g. firms with high asset tangibility), this factor seems to have an autonomous role and act as a constraint to income-increasing practices. Finally, our empirical evidence shows that the role of firm characteristics in explaining managers' accounting practices is smaller than the literature suggests. Only the investment opportunity set, the level of ownership dispersion and the asset tangibility seem to positively affect managers' incentives to undertake income-increasing practices.

The overall results indicates that institutional factors, mainly capital markets and taxalignment, are the main driving forces that explain differences in accounting practices in Europe, and that firm-specific characteristics play a small role. This means that the harmonization of accounting standards is not sufficient to achieve the comparability of accounting information at international level. These results are in line with previous evidence provided by Nobes (2011) and Kvaal \& Nobes (2012).

Nevertheless, the results of this paper should be treated with caution because they are subject to several limitations, all of them shared by similar studies available in the literature. The first two limitations are related to the way the dependent variable $(C M S)$, a proxy for the accounting practice strategies, is constructed. Firstly, the $C M S$ does not control specifically for the future reversion of the effects on income related to some of the accounting practices that compound this score (e.g. depreciation method, borrowing costs and development costs). However, the reversal effect of the accounting practices is a common limitation of studies on earnings managements and accruals (Missioner Piera 2004; Astami \& Tower, 2006) and given the nature and design of our study, we think this limitation may have an insignificant or no effect at all on the results. Secondly, the constructed dependent variable $(C M S)$ does not accurately measure the magnitude of the effect on reported income, as pointed out by previous 
studies on accounting practices (Zmijewski \& Hargeman, 1981; Jaafar \& McLeay, 2007). Hence, it does not capture the net income effect results from the accounting practices, as high expenses (lower income) that result from items with small magnitude may be mixed with lower expenses (higher income) from other items with greater magnitude.

A third limitation of this study concerns the relatively small country sample size across the thirteen European countries. Finding from a study with more observations per country will be more generalizable. However, as we pointed out in section 5.1 our sample is representative.

Finally, the last limitation arises from the high correlation between the institutional factors across countries and the difficulty of isolating the effect of each one (Leuz et al., 2003, Burgstahler et al., 2006). Notwithstanding this limitation, the results increase our understanding of the role of institutional factors in accounting policy practices under IFRS.

The fact that all European listed companies must now adopt the same set of accounting standards (IFRS) has opened up a wealth of new research opportunities. The present study makes a contribution to this field, but much more research is needed to enable the determinants of accounting practices to be fully understood. Future research could address this gap by exploring the firm and institutional determinants and consequences of a unique category of accounting practices such as goodwill valuation, development costs or inventory valuation. 


\section{Appendix 1. Sampling method}

A stratified simple random sample without replacement is used to construct the working sample. This method gives a balanced representation across countries and industries in Europe. We assumed that companies (observations) included within the same stratum (grouped by country and industry) are homogeneous and are, therefore, of equal importance. Thus, by choosing a random set of companies, each of them having the same probability of being chosen, a simple random sample is prepared for each stratum. To obtain the working sample we use a sampling method that followed a four-step process:

First, we defined the sample size by the following formula:

$$
n=\frac{\left[N * Z^{2} * P^{*}(1-P)\right]}{\left[e^{2 *(N-1)]+\left[Z^{2} * P^{*}(1-P)\right]}\right.}
$$

The number of observations in the sample size $(n=319)$ is calculated considering that $e$ is the precision or sample error $(\mathrm{e}=0.05)$; $\mathrm{Z}$ is the $\mathrm{z}$-score for a $95 \%$ confidence interval $(\mathrm{Z}=1.96) ; \mathrm{P}$ is the expected prevalence considering that firms can make either an incomeincreasing or income-decreasing practice $(\mathrm{P}=0.5)$; and $\mathrm{N}$ is the number of observations in the population $(\mathrm{N}=1,891)$.

Second, we defined the proportion of selected observations for each stratum as $g=n / N$. Since $\mathrm{n}=319$ and $\mathrm{N}=1,891$, the proportion of each stratum is $\mathrm{g}=0.17$.

Third, we define each stratum by country and industry. Our initial population has 13 countries and 4 industries, and consequently 52 strata.

Fourth, we take the working sample as $\mathrm{nf}=\mathrm{g} * \mathrm{~s}$ where $\mathrm{g}$ is the proportion of selected observations for each stratum $(\mathrm{g}=0.17)$, and s indicates the number of observations in each stratum. At least one observation is identified per stratum. The working sample (nf) consists of 344 companies. 


\section{References}

Abdel-khalik, A. R. (1985) The effect of LIFO-switching and firm ownership on executives' pay. Journal of Accounting Research, 23 (3), 427-447.

Ali, A. \& Hwang, L.-S. (2000) Country-specific factors related to financial reporting and the value relevance of accounting Data. Journal of Accounting Research, 38 (1), 1-21.

Ashbaugh, H. \& Pincus, M. (2001) Domestic accounting standards, International Accounting Standards, and the predictability of earnings. Journal of Accounting Research, 39 (3), 411-434.

Astami, E. W. \& Tower, G. (2006) Accounting-policy choice and firm characteristics in the Asia Pacific region: An international empirical test of Costly Contracting Theory. The International Journal of Accounting, 41 (1), 1-21.

Ball, R., Kothari, S. P. \& Robin, A. (2000) The effect of international institutional factors on properties of accounting earnings. Journal of Accounting and Economics, 29 (1), 1-51.

Ball, R., Robin, A. \& Wu, J. S. (2003) Incentives versus standards: properties of accounting income in four East Asian countries. Journal of Accounting and Economics, 36 (1-3), 235-270.

Ball, R. (2006) International Financial Reporting Standards (IFRS), pros and cons for investors. Accounting and Business Research. International Accounting Forum, 36 (Special Issue), 5-27.

Barth, M. \& Israeli, D. (2013) Disentangling Mandatory IFRS Reporting and Changes in Enforcement. Journal of Accounting and Economics, 56 (2-3), 178-188.

Barth, M., Landsman, W. \& Lang, M. (2008) International accounting standards and accounting quality. Journal of Accounting Research, 46 (3), 467-498.

Baker, C.R. \& Barbu, E. M. (2007) Trends in research on international accounting harmonization. The International Journal of Accounting, 42 (3), 272-304. 
Beneish, M. D. \& Press, E. (1993) Costs of technical violation of accounting-based debt covenants. The Accounting Review 68 (2), 233-257.

Burgstahler, D., Hail, L. \& Leuz, C. (2006) The importance of reporting incentives: earnings management in European private and public firms. The Accounting Review, 81 (5), $983-$ 1016.

Burgstahler, D. \& Eames, M. (2006) Management of earnings and analysts' forecasts to achieve zero and small positive earnings surprises. Journal of Business Finance and Accounting, 33 (5-6), 633-652.

Bushman, R. M. \& Piotroski, J. (2006) Financial reporting incentives for conservative accounting: The influence of legal and political institutions. Journal of Accounting and Economics, 42 (1-2), 107-148.

Cai, L. \& Wong, H. (2010) The effect of IFRS adoption on global market integration International. Business and Economics Research Journal, 9 (10), 25-34.

Cascino, S., Clatworthy, M., García Osma, B., Gassen, J., Imam, S., \& Jeanjean, T. (2014) Who uses financial reports and for what purpose? Evidence from capital providers. Available at SSRN: http://ssrn.com/abstract=2389752

Chizema, A. (2008) Institutions and voluntary compliance: The disclosure of individual executive pay in Germany. Corporate Governance: An International Review, 16 (4), 359374.

Christensen, H., Hail, L. \& Leuz, C. (2013) Mandatory IFRS reporting and changes in enforcement, Journal of Accounting and Economics, 56 (2-3), 147-177.

D'Arcy, A., (2001) Accounting classification and the international harmonisation debate —an empirical investigation. Accounting, Organizations and Society, 26 (4), 327-349. 
Daske, H., Hail, L., Leuz, C. \& Verdi, R. (2008) Mandatory IFRS reporting around the world: Early evidence on the economic consequences. Journal of Accounting Research, 46 (5), $1085-1142$.

Dechow, P., Sloan R. \& Sweeney, A. (1996) Causes and consequences of earnings manipulation, Contemporary Accounting Research, 13 (1), 1-36.

Degeorge, F., Patel, J. \& Zeckhauser, R. (1999) Earnings management to exceed thresholds. The Journal of Business, 72 (1), 1-33.

Dhaliwal, D. S. \& Heninger, W. G. (1999) The investment opportunity set and capitalization versus expensing methods of accounting choice. Accounting and Finance, 39 (2), 151175.

Dhaliwal, D. S. Salamon, G. L. \& Smith, E. D. (1982) The effect of owner versus management control on the choice of accounting methods. Journal of Accounting and Economics, 4 (1), 41-53.

Dopuch, N. \& Pincus, M. (1988) Evidence on the choice of inventory accounting methods: LIFO versus FIFO. Journal of Accounting Research, 26 (1), 28-59.

Doupnik, T.S. \& Salter, S.B. (1995) External environment, culture and accounting practice: A preliminary test of a general model of international accounting development. The International Journal of Accounting, 31 (3), 189-207.

European Securities and Markets Authority (ESMA) (2012) European enforcers review of impairment of goodwill and other intangible assets in the IFRS financial statements. Working paper.

Feroz, E. H., Park, K. \& Pastena, V. S. (1991) The financial and market effects of the SEC's accounting and auditing enforcement releases. Journal of Accounting Research, 29 (3), 107-142. 
Fields, T. D., Lys, T. Z. \& Vincent, L. (2001) Empirical research on accounting choice. Journal of Accounting and Economics, 31 (1-3), 255-307.

García Lara, J. M. \& Mora, A. (2004) Balance sheet versus earnings conservatism in Europe. European Accounting Review, 13 (2), 261-292.

Gee, M., Haller, A. \& Nobes, C. (2010) The Influence of tax on IFRS consolidated statements: The convergence of Germany and the UK. Accounting in Europe, 7 (1-2), $97-$ 122.

Giner, B. \& Rees, W. (2001) On the asymmetric recognition of good and bad news in France, Germany and the UK. Journal of Business Finance and Accounting, 28 (9-10), 12851331.

Gray, S. J. (1988) Towards a theory of cultural influence on the development of accounting systems internationally. Abacus, 24 (1), 1-15.

Haller, A. \& Wehrfritz, M. (2013) The impact of national GAAP and accounting traditions on IFRS policy selection: Evidence from Germany and the UK. Journal of International Accounting, Auditing and Taxation, 22 (1), 39-56.

Hand, J. R. M. \& Skantz, T. R. (1997) The economic determinants of accounting choices: The unique case of equity carve-outs under SAB 51. Journal of Accounting and Economics, $24(2), 175-203$.

Hope, O. K. (2003) Disclosure practices, enforcement of accounting standards, and analysts' forecast accuracy: An international study. Journal of Accounting Research, 41 (2), 235272.

Hung, M. (2001) Accounting standards and value relevance of financial statements: An international analysis. Journal of Accounting and Economics, 30 (3), 401-420.

IMD (2000) World Competitiveness Yearbook, Lausanne. 
Isidro, H. \& Raonic, I. (2012) Firm incentives, institutional complexity and the quality of "harmonized" accounting numbers. The International Journal of Accounting, 47 (4), 407436.

Jaafar, A. \& McLeay, S. (2007) Country effects and sector effects on the harmonisation of accounting policy choice. Abacus, 43 (2), 156-189.

Jensen M.C. \& Meckling, W.H. (1976) Theory of the firm: Managerial behavior, agency costs and ownership structure. Journal of Financial Economics, 3 (4), 305-360.

Joos, P. \& Lang, M. (1994) The Effects of accounting diversity: Evidence from the European Union. Journal of Accounting Research, 32 (3), 141-168.

Kaufmann, D., Kraay, A. \& Mastruzzi. M. (2007) Governance matters VI: aggregate and individual governance indicators 1996-2006. Washington, DC: The World Bank.

Kothari, S. P., Laguerre, T. E. \& Leone, A. J. (2002) Capitalization versus expensing: Evidence on the uncertainty of future earnings from capital expenditures versus $R \& D$ outlays. Review of Accounting Studies, 7 (4), 355-382.

KPMG \& Von Keitz, I. (2006) The application of IFRS: Choices in practice. London: KPMG.

Kvaal, E. \& Nobes, C. (2010) International differences in IFRS policy choice. Accounting and Business Research, 40 (2), 173-187.

Kvaal, E. \& Nobes, C. (2012) IFRS policy changes and the continuation of national patterns of IFRS practice. European Accounting Review, 21 (2), 343-371.

La Porta, R., Lopez-de-Silanes, F. \& Shleifer, A. (1999) Corporate ownership around the World. Journal of Finance, 54 (2), 471-517.

La Porta, R., Lopez-de-Silanes, F. \& Shleifer, A. (2006) What works in securities laws? Journal of Finance, 61 (1), 1-32.

Leuz, C., Nanda, D. \& Wysocki, P. D. (2003) Earnings management and investor protection: an international comparison. Journal of Financial Economics, 69 (3), 505-527. 
Leuz, C. (2010) Different Approaches to Corporate Reporting Regulation: How Jurisdictions Differ and Why. Chicago Booth Initiative on Global Markets Research Paper No. 53; ECGI - Law Working Paper No. 156/2010.

Lourenço, I. \& Curto J. (2010) Determinants of the accounting choice between alternative reporting methods for interests in jointly controlled entities. European Accounting Review, 19 (4), 739-777.

Missonier-Piera, F. (2004) Economic determinants of multiple accounting method choices in a Swiss context. Journal of International Financial Management and Accounting, 15 (2), 118-144.

Missonier-Piera, F. (2007) Motives for fixed-asset revaluation: An empirical analysis with Swiss data. The International Journal of Accounting, 42 (2), 186-205.

Niehaus, G. R. (1989) Ownership structure and inventory method choice. The Accounting Review, 64 (2), 269- 284.

Nobes, C. (1983) A judgemental international classification of financial reporting practices. Journal of Business Finance and Accounting, 10 (1), 1-19.

Nobes, C. (1998) Towards a General Model of the Reasons for International Differences in Financial Reporting. Abacus, 34 (2), 162-187.

Nobes, C. (2011) IFRS practices and the persistence of accounting system classification. Abacus, 47(3), 267-283.

Nobes C. (2013). The continued survival of international differences under IFRS. Accounting and Business Research, 43 (2), 83-111.

Nobes, C. W. \& Stadler, C. (2013) How arbitrary are international accounting classifications? Lessons from centuries of classifying in many disciplines, and experiments with IFRS data. Accounting, Organizations and Society, 38 (8), 573-595. 
Quagli, A. \& Avallone, F. (2010) Fair value or cost model? Drivers of choice for IAS 40 in the real estate industry. European Accounting Review, 19 (3), 461-493.

Rahman, A., Perera, H., \& Ganesh, S. (2002) Accounting practice harmony, accounting regulation and firm characteristics. Abacus, 38 (1), 46-74.

Ramanna, K. \& Watts, R. L. (2012) Evidence on the use of unverifiable estimates in required goodwill impairment. Review of Accounting Studies, 17 (4), 749-780.

Skinner, D. J. (1993) Asset structure, financing policy, and accounting choice: Preliminary evidence. Journal of Accounting and Economics, 16 (4), 407-445.

Smith, C. W. \& Watts, R. (1992) The investment opportunity set and corporate financing, dividend, and compensation policies. Journal of Financial Economics, 32 (3), 263-192.

Stolowy, H. \& Ding, Y. (2003) Regulatory flexibility and management opportunism in the choice of alternative accounting standards: an illustration based on large French groups, The International Journal of Accounting, 38 (2), 195-213.

Watts, R. \& Zimmerman, J.L. (1978) Towards a positive theory of the determination of accounting standards. The Accounting Review, 53 (1), 112-134.

Watts, R. (2003) Conservatism in accounting part I: explanations and implications. Accounting Horizons 17 (3), 207-221.

Williamson, O. E. (1983) Credible commitments: using hostages to support exchange, American Economic Review, 73 (4), 519-38.

Zmijewski, M. \& Hagerman, R.L. (1981) An income strategy approach to the positive theory of accounting standard setting/choice. Journal of Accounting and Economics, 3 (2), 129149. 
Table 1. Values assigned to each accounting policy practice

\begin{tabular}{|c|c|c|c|c|}
\hline Accounting Policy & $N D / N A$ & Decreasing & Mixed & Increasing \\
\hline$I M S$ value & 0 & 0 & 1 & 2 \\
\hline $\begin{array}{l}\text { Inventory valuation } \\
(I N V)\end{array}$ & ND/NA & Average costs & Mixed & $\begin{array}{l}\text { FIFO: first in } \\
\text { first out }\end{array}$ \\
\hline $\begin{array}{l}\text { Depreciation } \\
\text { methods }(D E P)\end{array}$ & ND/NA & $\begin{array}{l}\text { Accelerated } \\
\text { method }\end{array}$ & Mixed & $\begin{array}{l}\text { Straight-line } \\
\text { method }\end{array}$ \\
\hline $\begin{array}{l}\text { Valuation methods } \\
\text { for PP\&E (PPE) }\end{array}$ & ND/NA & $\begin{array}{l}\text { Fair value: } \\
\text { recognition of } \\
\text { gains in equity or } \\
\text { through profit \& } \\
\text { loss account }\end{array}$ & Mixed & Cost model \\
\hline $\begin{array}{l}\text { Borrowing costs } \\
(B C)\end{array}$ & ND/NA & $\begin{array}{l}\text { Through profit \& } \\
\text { loss account }\end{array}$ & & Capitalised \\
\hline $\begin{array}{l}\text { Development costs } \\
(D C)\end{array}$ & ND/NA & $\begin{array}{l}\text { Through profit \& } \\
\text { loss account }\end{array}$ & & Partly capitalised \\
\hline $\begin{array}{l}\text { Goodwill } \\
\text { impairment }(G W I)\end{array}$ & ND/NA & Impairment & & Non-impairment \\
\hline
\end{tabular}


Table 2. Sample selection by country and industry

\begin{tabular}{|c|c|c|c|c|c|c|c|}
\hline Country & $N$ & $n f$ & $\%$ & Industry & $N$ & $n f$ & $\%$ \\
\hline Austria & 47 & 9 & 19 & Transportation, Communications, & & & \\
\hline Belgium & 76 & 14 & 18 & Electricity, Gas, \& Health Services & 212 & 42 & 20 \\
\hline Denmark & 60 & 12 & 20 & Wholesale Trade and Retail Trade & 234 & 46 & 20 \\
\hline Finland & 102 & 19 & 19 & Services & 525 & 94 & 18 \\
\hline France & 348 & 61 & 18 & Manufacturing & 920 & 162 & 18 \\
\hline Germany & 406 & 70 & 17 & & & & \\
\hline Ireland & 16 & 4 & 25 & & & & \\
\hline Italy & 168 & 30 & 18 & & & & \\
\hline Netherlands & 94 & 19 & 20 & & & & \\
\hline Portugal & 34 & 8 & 24 & & & & \\
\hline Spain & 75 & 15 & 20 & & & & \\
\hline Sweden & 201 & 35 & 17 & & & & \\
\hline UK & 264 & 48 & 18 & & & & \\
\hline Total & 1,891 & 344 & 18 & Total & 1,891 & 344 & 18 \\
\hline
\end{tabular}


Table 3. Accounting policy practice frequency

\begin{tabular}{|c|c|c|c|c|c|c|c|c|c|c|c|c|c|c|c|}
\hline Country & $A U$ & $B E$ & $D E$ & $F I$ & $F R$ & $G E$ & $I R$ & $I T$ & $N E$ & $P O$ & $S P$ & $S W$ & $U K$ & $n$ & $\%$ \\
\hline Total Sample & 9 & 14 & 12 & 19 & 61 & 70 & 4 & 30 & 19 & 8 & 15 & 35 & 48 & 344 & 100 \\
\hline \multicolumn{16}{|c|}{ Inventory valuation methods } \\
\hline ND/ NA & & 2 & 2 & 2 & 21 & 31 & 1 & & 5 & & 2 & 9 & 20 & 95 & 28 \\
\hline Decreasing & 8 & 5 & 4 & 5 & 19 & 30 & & 23 & 4 & 8 & 9 & 1 & 5 & 121 & 35 \\
\hline Mixed & 1 & 2 & & 6 & 2 & 2 & & & 1 & & 1 & & 2 & 17 & 5 \\
\hline Increasing & & 5 & 6 & 6 & 19 & 7 & 3 & 7 & 9 & & 3 & 25 & 21 & 111 & 32 \\
\hline \multicolumn{16}{|c|}{ Depreciation methods } \\
\hline ND & & & 1 & 2 & 5 & 4 & 2 & 6 & 1 & & & 5 & 6 & 32 & 9 \\
\hline Decreasing & & & & & & 1 & & & & 1 & & & & 2 & 1 \\
\hline Mixed & & & & & 3 & 1 & & & & & & & & 4 & 1 \\
\hline Increasing & 9 & 14 & 11 & 17 & 53 & 64 & 2 & 24 & 18 & 7 & 15 & 30 & 42 & 306 & 89 \\
\hline \multicolumn{16}{|c|}{ Valuation methods $P P \& E$} \\
\hline $\mathrm{ND}$ & & & & & 2 & & & & & & & & & 2 & 0 \\
\hline Decreasing & & & & & & & & & & & & & 1 & 1 & 0 \\
\hline Mixed & 1 & & & & 2 & 1 & & 1 & 1 & 1 & 1 & & 1 & 9 & 3 \\
\hline Increasing & 8 & 14 & 12 & 19 & 57 & 69 & 4 & 29 & 18 & 7 & 14 & 35 & 46 & 332 & 97 \\
\hline \multicolumn{16}{|c|}{ Borrowing costs } \\
\hline $\mathrm{ND} / \mathrm{NA}$ & 3 & 2 & 5 & 9 & 23 & 18 & 1 & 8 & 14 & 3 & 3 & 14 & 27 & 130 & 38 \\
\hline Decreasing & 3 & 11 & 4 & 9 & 34 & 46 & 1 & 16 & 4 & 2 & 3 & 19 & 15 & 167 & 49 \\
\hline Increasing & 3 & 1 & 3 & 1 & 4 & 6 & 2 & 6 & 1 & 3 & 9 & 2 & 6 & 47 & 14 \\
\hline \multicolumn{16}{|c|}{ Development costs } \\
\hline ND/ NA & 4 & 2 & 3 & 1 & 18 & 24 & 2 & 10 & 8 & & 4 & 7 & 20 & 103 & 30 \\
\hline Decreasing & 1 & 6 & 1 & 8 & 16 & 22 & 1 & 6 & 2 & 4 & 2 & 6 & 12 & 87 & 25 \\
\hline Increasing & 4 & 6 & 8 & 10 & 27 & 24 & 1 & 14 & 9 & 4 & 9 & 22 & 16 & 154 & 45 \\
\hline \multicolumn{16}{|c|}{ Goodwill impairment } \\
\hline $\mathrm{ND} / \mathrm{NA}$ & & 1 & 1 & & 5 & 10 & & 2 & 1 & & & 3 & 6 & 29 & 8 \\
\hline Decreasing & & & 1 & 2 & 13 & 13 & 1 & 2 & 5 & 3 & 2 & 4 & 10 & 56 & 17 \\
\hline Increasing & 9 & 13 & 10 & 17 & 43 & 47 & 3 & 26 & 13 & 5 & 13 & 28 & 32 & 259 & 75 \\
\hline
\end{tabular}

This table provides descriptive statistics for the accounting policy practice frequency. $A U$ stands for Austria, $B E$ for Belgium, $D E$ for Denmark, $F I N$ for Finland, $F R$ for France, $G E$ for Germany, $I R$ for Ireland, $I T$ for Italy, $N E$ for Netherlands, $P O$ for Portugal, $S P$ for Spain, $S W$ for Sweden and $U K$ for the United Kingdom. $n$ is the number of companies for each accounting policy practice. $\%$ is the frequency percentage of each accounting policy. ND/NA indicates that the practice is Non-Disclosed or NonApplicable; Decreasing indicates that the managers' practice is an income-decreasing accounting practice; Mixed indicates that more than one policy practice has been chosen so there is a mixed (income-increasing and income-decreasing) impact on income. Increasing indicates that the managers' practice is incomeincreasing. 
Table 4. Descriptive statistics

\begin{tabular}{|c|c|c|c|c|c|c|c|c|c|c|c|}
\hline & \multirow[b]{2}{*}{$\mathrm{n}$} & \multirow[b]{2}{*}{ CMS } & \multicolumn{3}{|c|}{ Institutional factors } & \multicolumn{6}{|c|}{ Firm Characteristics } \\
\hline & & & LMK & TAX & ENF & LEV & DISP & ASP & IOS & TAN & SIZE \\
\hline Austria & 9 & 1.42 & $-4.11(1)$ & $0.34(1)$ & $0.17(0)$ & 0.59 & 52.96 & 0.01 & 0.88 & 0.31 & 12.6 \\
\hline Belgium & 14 & 1.43 & $-7.66(1)$ & $0.40(1)$ & $0.15(0)$ & 0.67 & 52.15 & 0.03 & 1.45 & 0.27 & 12.5 \\
\hline Denmark & 12 & 1.67 & $-6.91(1)$ & $0.00(0)$ & $0.37(0)$ & 0.47 & 53.48 & 0.03 & 2.44 & 0.38 & 12.1 \\
\hline Finland & 19 & 1.48 & $-10.71(0)$ & $0.28(0)$ & $0.32(0)$ & 0.50 & 72.98 & 0.05 & 1.19 & 0.33 & 12.3 \\
\hline France & 61 & 1.42 & $-8.19(0)$ & $0.40(1)$ & $0.77(1)$ & 0.63 & 44.75 & 0.03 & 1.15 & 0.17 & 12.5 \\
\hline Germany & 70 & 1.33 & $-4.38(1)$ & $0.53(1)$ & $0.22(0)$ & 0.51 & 67.80 & 0.04 & 1.16 & 0.23 & 11.8 \\
\hline Ireland & 4 & 1.70 & $-5.66(1)$ & $0.00(0)$ & $0.37(0)$ & 0.63 & 69.59 & 0.00 & 1.01 & 0.39 & 13.1 \\
\hline Italy & 30 & 1.38 & $-4.49(1)$ & $0.37(1)$ & $0.48(1)$ & 0.61 & 63.12 & 0.00 & 0.78 & 0.30 & 13.3 \\
\hline Netherlands & 19 & 1.64 & $-9.29(0)$ & $0.00(0)$ & $0.47(1)$ & 0.63 & 77.13 & 0.02 & 1.68 & 0.22 & 12.3 \\
\hline Portugal & 8 & 1.16 & $-3.61(1)$ & 0.37 (1) & $0.58(1)$ & 0.86 & 56.85 & 0.00 & 0.69 & 0.46 & 13.5 \\
\hline Spain & 15 & 1.56 & $-8.49(0)$ & $0.35(1)$ & $0.33(0)$ & 0.51 & 72.16 & 0.00 & 1.79 & 0.42 & 13.1 \\
\hline Sweden & 35 & 1.67 & $-10.9(0)$ & $0.28(1)$ & $0.50(1)$ & 0.51 & 69.97 & 0.03 & 1.58 & 0.18 & 12.0 \\
\hline UK & 48 & 1.59 & $-13.41(0)$ & $0.00(0)$ & $0.68(1)$ & 0.58 & 71.65 & 0.03 & 1.50 & 0.20 & 12.1 \\
\hline Mean & & 1.47 & $-8.00(0.43)$ & $0.30(0.75)$ & $0.47(0.58)$ & 0.57 & 63.3 & 0.03 & 1.13 & 0.25 & 12.3 \\
\hline Std. dev. & & 0.35 & $3.19(0.49)$ & $0.19(0.42)$ & $0.21(0.49)$ & 0.24 & 26.85 & 0.06 & 1.38 & 0.2 & 1.93 \\
\hline Median & & 1.50 & $-8.19(0.00)$ & $0.37(1.00)$ & $0.48(1.00)$ & 0.58 & 65.87 & 0 & 0.91 & 0.19 & 12.1 \\
\hline $\mathrm{n}$ & & 344 & 344 & 344 & 344 & 344 & 344 & 344 & 344 & 344 & 344 \\
\hline
\end{tabular}

This table provides descriptive statistics for the variables of the model. $n$ is the number of observations; $C M S$ is the composite score; $L M K$ is the negative value of the ratio of market capitalisation of all listed companies stock to GDP; TAX is a variable provided by Burgstaler et al (2006) which is measured as the average corporate tax rate in percent of earnings before taxes obtained from IMD World Competitiveness Yearbook (2000) and takes values different from 0 only when the tax and financial accounting are closely aligned; ENF is the index of La Porta (2006) for public enforcement. In parenthesis are the transformed binary variables ( $L M K D, T A X D$ and $E N F D)$ by splitting by the median of the three institutional factors continuous variables ( $L M K$, TAX and $E N F$ ) (except for TAX where we use 0 percent as a cut-off). $L E V$ is leverage ratio measured as total assets to total debt; DISP, the percentage of widely held shares; ASP, the level of asset specificity measured by total R\&D expenses deflated by total assets; IOS, the ratio of market value of the firm to the book value of assets; TAN, the tangibility of assets measured by total property, plant and equipment deflated by total assets; SIZE, the logarithm of total assets. Variables $L E V, D I S P, A S P, I O S, T A N$ and SIZE are all winsorized at $1 \%$ and $99 \%$. The mean values for the variables $C M S, L E V, D I S P, A S P, I O S, T A N$ and SIZE are presented. 
Table 5. Pearson (above) and Spearman (below) Correlation matrix $(n=344)$

\begin{tabular}{|c|c|c|c|c|c|c|c|c|c|c|c|c|c|}
\hline & CMS & LMK & LMKD & TAX & TAXD & ENF & ENFD & LEV & DISP & ASP & IOS & TAN & SIZE \\
\hline CMS & 1 & $-0.28 * * *$ & $-0.22 * * *$ & $-0.30 * * *$ & $-0.23 * * *$ & $0.09 * *$ & $0.11 * *$ & -0.06 & $0.13^{* *}$ & 0.05 & $0.19 * * *$ & -0.02 & $-0.11 * *$ \\
\hline MK & $-0.31 * * *$ & 1 & $0.84 * * *$ & $0.73 * * *$ & $0.56 * * *$ & $-0.54 * * *$ & $-0.48 * * *$ & 0.05 & -0.11 & -0.12 & $-0.13^{* *}$ & $0.13 * *$ & 0.05 \\
\hline MKD & $-0.24 * * *$ & $0.87 * * *$ & 1 & $0.47 * * *$ & $0.27 * * *$ & $-0.69 * * *$ & $-0.57 * * *$ & 0.00 & -0.02 & -0.07 & $-0.09 *$ & $0.15^{* * *}$ & 0.01 \\
\hline TAX & $-0.33 * * *$ & $0.75^{* * *}$ & $0.51 * * *$ & 1 & $0.91 * * *$ & $-0.39 * * *$ & $-0.40 * * *$ & 0.00 & $-0.14 * *$ & -0.03 & $-0.15^{* *}$ & -0.02 & -0.01 \\
\hline TAXD & $-0.23 * * *$ & $0.52 * * *$ & $0.27 * * *$ & $0.76^{* * *}$ & 1 & $-0.28 * * *$ & $-0.26 * * *$ & 0.01 & $-0.14 * *$ & -0.05 & $-0.14 * *$ & 0.01 & 0.04 \\
\hline ENF & $0.11 * *$ & $-0.55 * * *$ & $-0.70 * * *$ & $-0.31 * * *$ & $-0.22 * * *$ & 1 & $0.87 * * *$ & $0.14^{* *}$ & $-0.15 * *$ & 0.01 & 0.00 & $-0.17 * * *$ & 0.07 \\
\hline ENFD & $0.12 * *$ & $-0.53 * * *$ & $-0.57 * * *$ & $-0.40 * * *$ & $-0.26 * * *$ & $0.86 * * *$ & 1 & $0.16^{* *}$ & -0.06 & -0.02 & -0.02 & $-0.17 * * *$ & 0.08 \\
\hline LEV & -0.04 & 0.05 & -0.01 & 0.02 & 0.00 & $0.14^{* *}$ & $0.17 * * *$ & 1 & -0.08 & -0.25 & $-0.24 * * *$ & $0.14 * *$ & $0.28 * * *$ \\
\hline DISP & $0.12 * *$ & $-0.10 * *$ & -0.01 & $-0.13 * *$ & $-0.13 * *$ & $-0.16^{* *}$ & -0.07 & -0.06 & 1 & 0.12 & $0.09 *$ & 0.01 & -0.06 \\
\hline ASP & -0.04 & $-0.09 *$ & -0.07 & 0.00 & 0.01 & -0.05 & $-0.10 * *$ & $-0.24 * * *$ & $0.12 * *$ & 1 & $0.33 * * *$ & $-0.28 * * *$ & $-0.27 * * *$ \\
\hline IOS & $0.15^{* *}$ & $-0.15^{* *}$ & $-0.13 * *$ & $-0.16^{* *}$ & $-0.16^{* *}$ & 0.01 & -0.02 & $-0.33 * * *$ & 0.06 & $0.19 * *$ & 1 & -0.05 & $-0.23 * * *$ \\
\hline TAN & -0.07 & $0.14^{* *}$ & $0.17 * *$ & -0.05 & 0.03 & $-0.17 * *$ & $-0.18 * * *$ & $0.15^{* *}$ & -0.01 & $-0.16^{* *}$ & -0.07 & 1 & $0.35 * * *$ \\
\hline SIZE & $-0.12 * *$ & 0.00 & -0.01 & -0.07 & 0.01 & 0.08 & $0.09 *$ & $0.32 * * *$ & -0.08 & -0.08 & $-0.15 * *$ & $0.39 * * *$ & 1 \\
\hline
\end{tabular}

This table presents Pearson (above diagonal) and Spearman (below diagonal) correlations between the variables of our main model. Definition of the variables as per Table 4. The significance of the coefficients is as follows: *,***** stand for $0.1,0.05$ and 0.01 level of significance, respectively. 
Table 6. Institutional determinants of accounting practice under IFRS

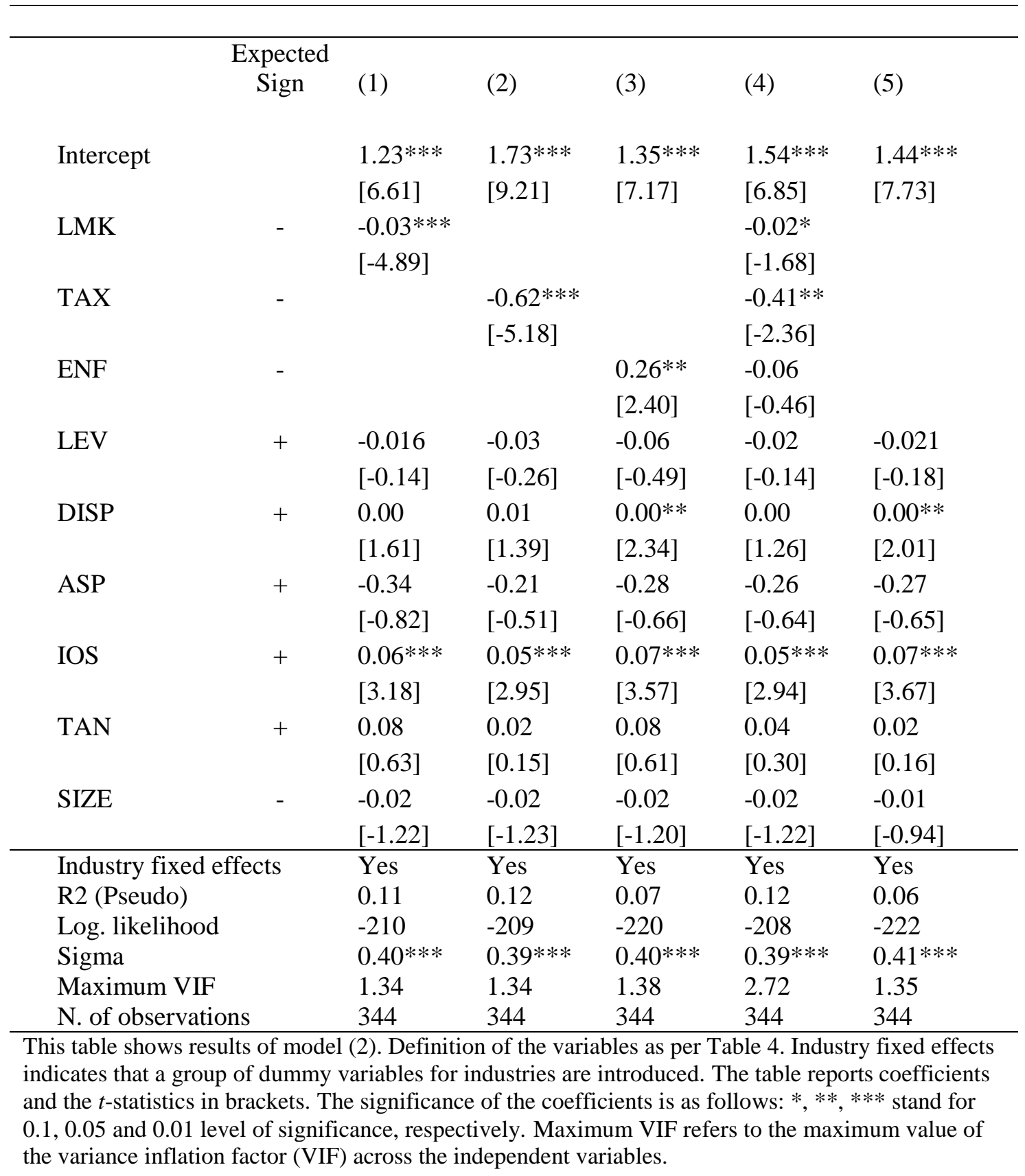


Table 7. Institutional determinants of accounting practice under IFRS: interaction of firms characteristics

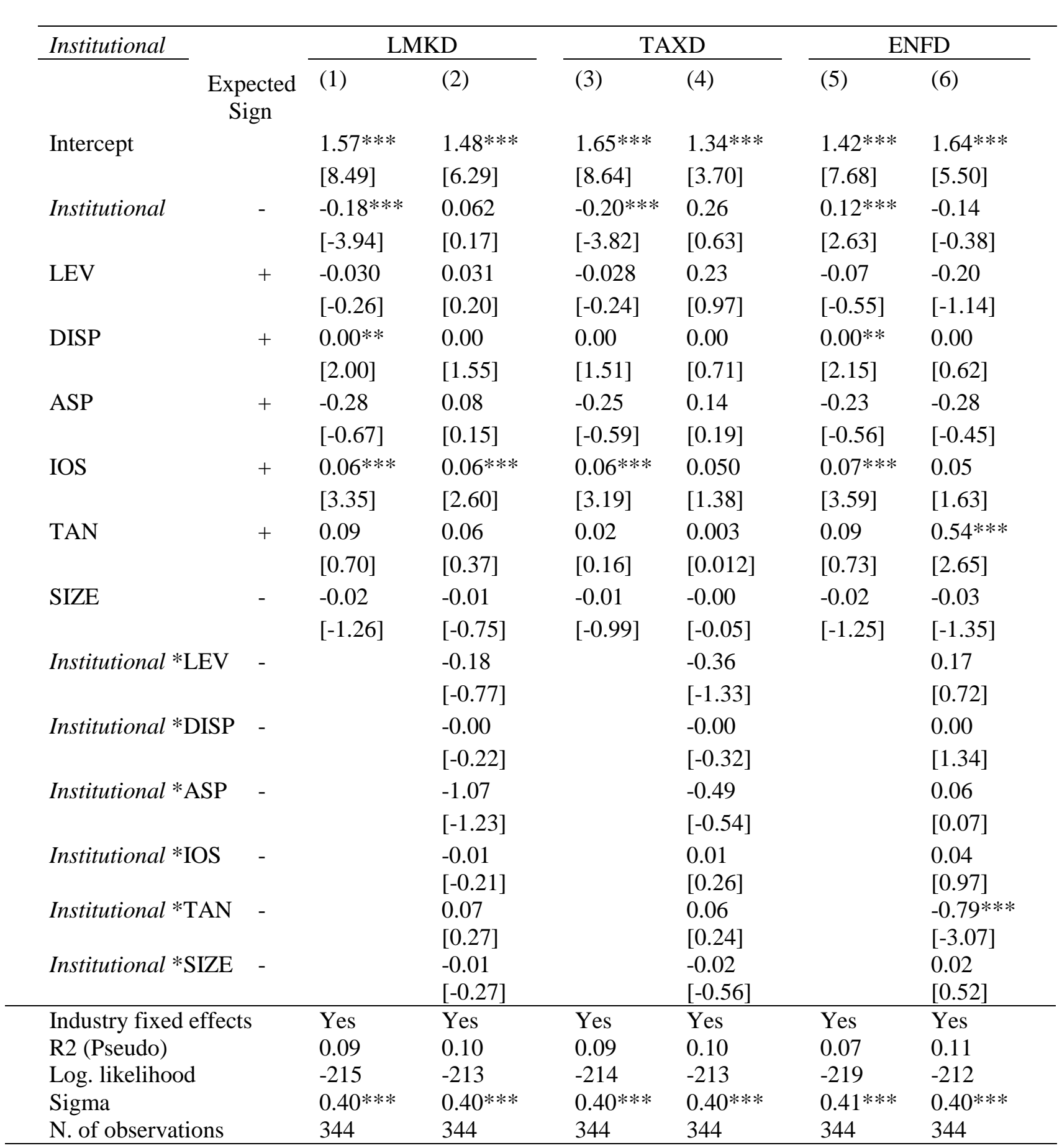

This table shows results of model (3). Definition of the variables as per Table 4. Industry fixed effects indicates that a group of dummy variables for industries are introduced. The table reports coefficients and the $t$-statistics in brackets. The significance of the coefficients is as follows: *,**,*** stand for $0.1,0.05$ and 0.01 level of significance, respectively. 